\title{
New Cultivars
}

Keywords: cultivar: Drosera spatulata 'Ruby Slippers', Utricularia reniformis 'Big Sister', Utricularia reniformis 'Enfant Terrible'.

\section{Drosera spatulata 'Ruby Slippers'}

Submitted: 18 March 2003

In December of 2000 I sowed and germinated some seed originally obtained earlier from the Australian Carnivorous Plant Society seed bank. It was labeled as Drosera spatulata purported to have been collected from Kowloon Peak, Hong Kong. As the plants matured, I noticed that the plants took on a dark red pigmentation and have maintained that hue ever since (see Front Cover)

The entire leaf petiole and blade exhibit dark maroon to burgundy coloration when grown in strong light, though they can exhibit more green if grown in a reduced light environment. Mature plants reach $2.5 \mathrm{~cm}$ in diameter when grown under strong light, but may be somewhat larger if grown in lower light levels. The underside of the leaves are covered with long (3-4 mm) white hairs, parallel to the petiole, and which are visible on the newly forming leaves before they unfurl, and on the underside of fully formed leaves. The leaves are wedge shaped, having a very short petiole in proportion to the leaf blade, very reminiscent of Drosera brevifolia, though the leaf lamina are slightly wider, the plants are overall slightly larger, and more robust in appearance.

I grow many different clones of Drosera spatulata, all under fluorescent lights in the same conditions, but specimens of Drosera 'Ruby Slippers' are by far the most intensely red plants. The color of Drosera spatulata from Fraser Island, Queensland, Australia is similar, but those plants are somewhat larger.

Drosera 'Ruby Slippers' may be propagated by seed or vegetative means, but no matter how propagated the progeny must exhibit the dark red color and the form of the standard when grown under conditions of strong light.

They are tender perennials, persisting throughout the year. Mine have been growing continuously since germinating in December of 2000.

\section{-William Joseph Clemens - 13090 W. Camino de Conejo - Tucson, Arizona 85743-8872 • USA}

\section{Utricularia reniformis 'Big Sister'}

Submitted: 15 March 2003

Some of the most spectacular Utricularia species are classified in the section Iperua. These plants include leafy leviathans such as $U$. nelumbifolia - with huge peltate leaves up to $10 \mathrm{~cm}$ in diameter on $45 \mathrm{~cm}$ long stalks - and floral goliaths such as $U$. humboldtii with flowers up to 10 $\mathrm{cm}$ across! Utricularia reniformis lives up to the high standards set by its brethren plants. Its reniform leaves are up to $14 \mathrm{~cm}$ in diameter, and crown petioles up to $65 \mathrm{~cm}$ tall (see Taylor, 1989, The Genus Utricularia-a Taxonomic Monograph, Her Majesty's Stationery Office, London)! Its flowers are large and ornate, with blue, yellow, violet, and purple elements.

There are two types of Utricularia reniformis in cultivation. Popular with horticulturists, these two plants are clearly in need of cultivar designation; we seek to correct this deficit.

The primary distinction between the two cultivars of Utricularia reniformis is size. At maturity, Utricularia reniformis 'Big Sister' consistently produces large leaves i.e. at least $8 \mathrm{~cm}$ in diameter (see Back Cover). One of us (MS) has even observed a greenhouse specimen with 
leaves $22.2 \mathrm{~cm}$ in diameter, on a petiole $46 \mathrm{~cm}$ tall! Mature Utricularia reniformis 'Big Sister' specimens do not produce abundant small leaves (in contrast with Utricularia reniformis 'Enfant Terrible', described below'). A second feature distinguishing the two cultivars is the incision into the leaf where the petiole attaches to the leaf blade. In Utricularia 'Big Sister', this cut is narrow (i.e. acute). See, for examples, the leaf lamina outlines in Taylor (1989), Figure 131 (figure elements $2,3,4$ ). Floral characters are not considered important in distinguishing these two cultivars.

Of the two Utricularia reniformis cultivars, Utricularia reniformis 'Big Sister' seems to be slightly more challenging to grow well. The giant leaves are not developed to perfection if the conditions are inadequate. This plant may perhaps be treated best as an epiphyte, and should be grown in a comparatively light, airy mix. Humidity should be high.

Certainly Utricularia reniformis 'Big Sister' can be propagated easily by vegetative means, but plants produced by cross pollinating separate clones would be considered Utricularia reniformis 'Big Sister' as long as they produced the large leaves characteristic of the cultivar. Utricularia seedlings resulting from self-pollinations are sometimes nonvigorous, so we recommend the progeny of self pollinations (or even cross pollinations of plants that may be of closely related lineages) should be carefully evaluated for horticultural value. It is not known if the various clones of Utricularia reniformis 'Big Sister' in cultivation are genetically identical.

Additional aspects of this cultivar are discussed in the article on page 47.

\section{—Barry Rice •P.O. Box 72741 • Davis, California • USA • barry@sarracenia.com \\ -Miloslav Studnicka • Botanic Gardens Liberec - Purkynova 1 -460 01 Liberec • Czech Republic}

\section{Utricularia reniformis 'Enfant Terrible'}

Submitted: 15 March 2003

Utricularia reniformis 'Enfant Terrible' is the smaller form of this species in cultivation. Its leaves never exceed approximately $4 \mathrm{~cm}$ in size, on petioles approximately $12 \mathrm{~cm}$ tall (see Figure 1). An interesting feature of this cultivar is the production of a carpet of minute ground-leaves under the large aerial-leaves. The diameters of these leaves range from as small as only a few $\mathrm{mm}$ to as large as a few $\mathrm{cm}$ (see Figure 2). Depending upon the cultivation conditions, Utricularia reniformis 'Enfant Terrible' may only have large aerial-leaves, minute groundleaves, or both. In a relatively dry California greenhouse, one of us (BR) has observed this plant to grow only aerial leaves during the cool, amenable winter, and ground-leaves during the hotter, fierce summer.

Another feature distinguishing Utricularia reniformis 'Enfant Terrible' from Utricularia reniformis 'Big Sister' is in the nature of the leaf incision, where the petiole attaches to the leaf blade. In Utricularia reniformis 'Enfant Terrible', the incision is typically obtuse (instead of acute, as in Utricularia reniformis 'Big Sister'). For examples, refer to the leaf lamina drawings in Taylor (1989), in particular Figure 131 (figure elements 5,6,7).

Utricularia reniformis 'Enfant Terrible' is often confused with Utricularia nephrophylla, which has $0.1-1 \mathrm{~cm}$ leaf blades. While the ground-leaves of Utricularia reniformis 'Enfant Terrible' can mimic the appearance of Utricularia nephrophylla, the larger aerial leaves of Utricularia reniformis 'Enfant Terrible' are diagnostic. The flowers of these two species are also quite different.

Horticulturists who possess Utricularia reniformis 'Enfant Terrible' are sometimes frustrated by this plant when, despite heroic cultivation measures, it does not produce gigantic leaves. This is not Utricularia reniformis 'Big Sister'! On the other hand, Utricularia reniformis 'Enfant Terrible' survives easily in conditions where Utricularia reniformis 'Big Sister' might wither and perish.

Utricularia reniformis 'Enfant Terrible' is grown easily in a variety of mixes, but prefers a relatively light soil. It can be propagated vegetatively very easily. Plants propagated by sexual 


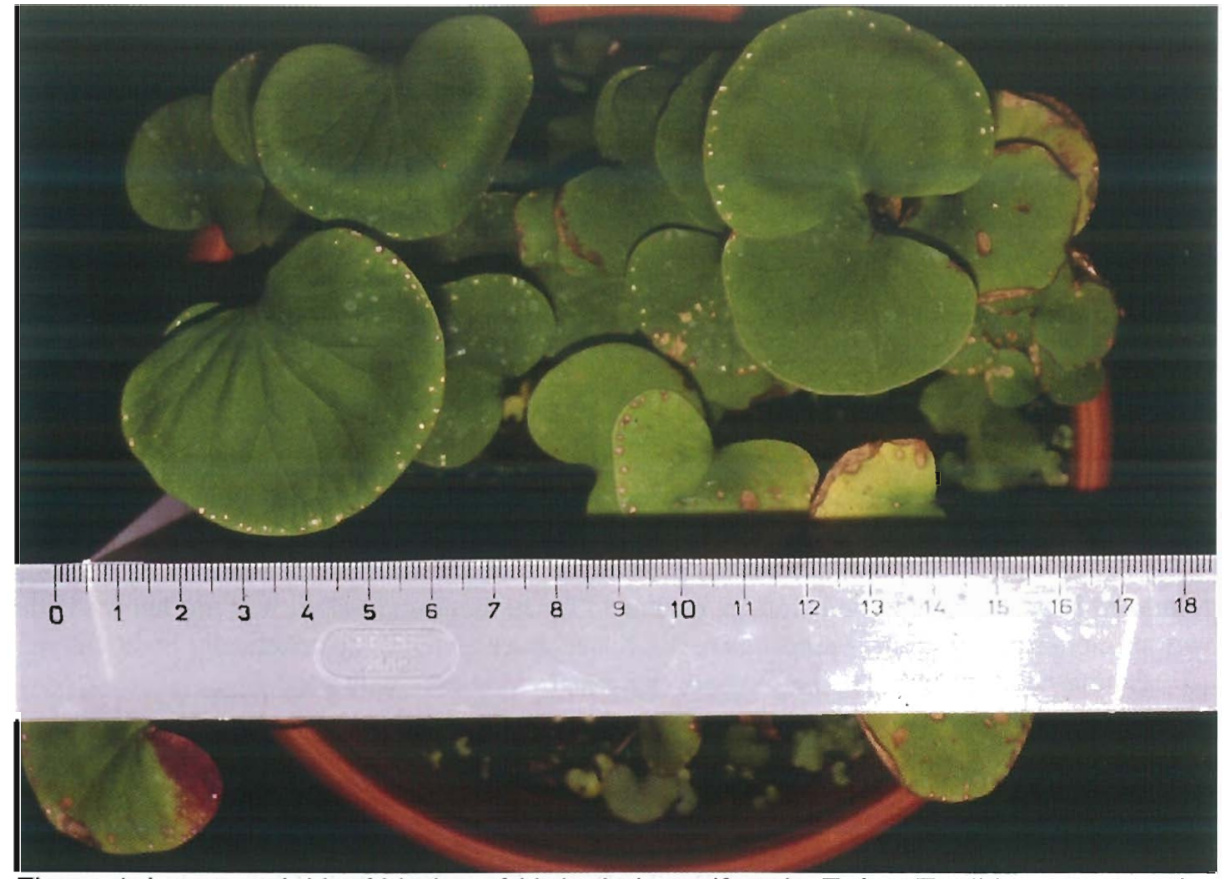

Figure 1: Large aerial leaf blades of Utricularia reniformis Enfant Terribie, grown at the Botanic Gardens Liberec. Photograph by Miloslav Studnicka.

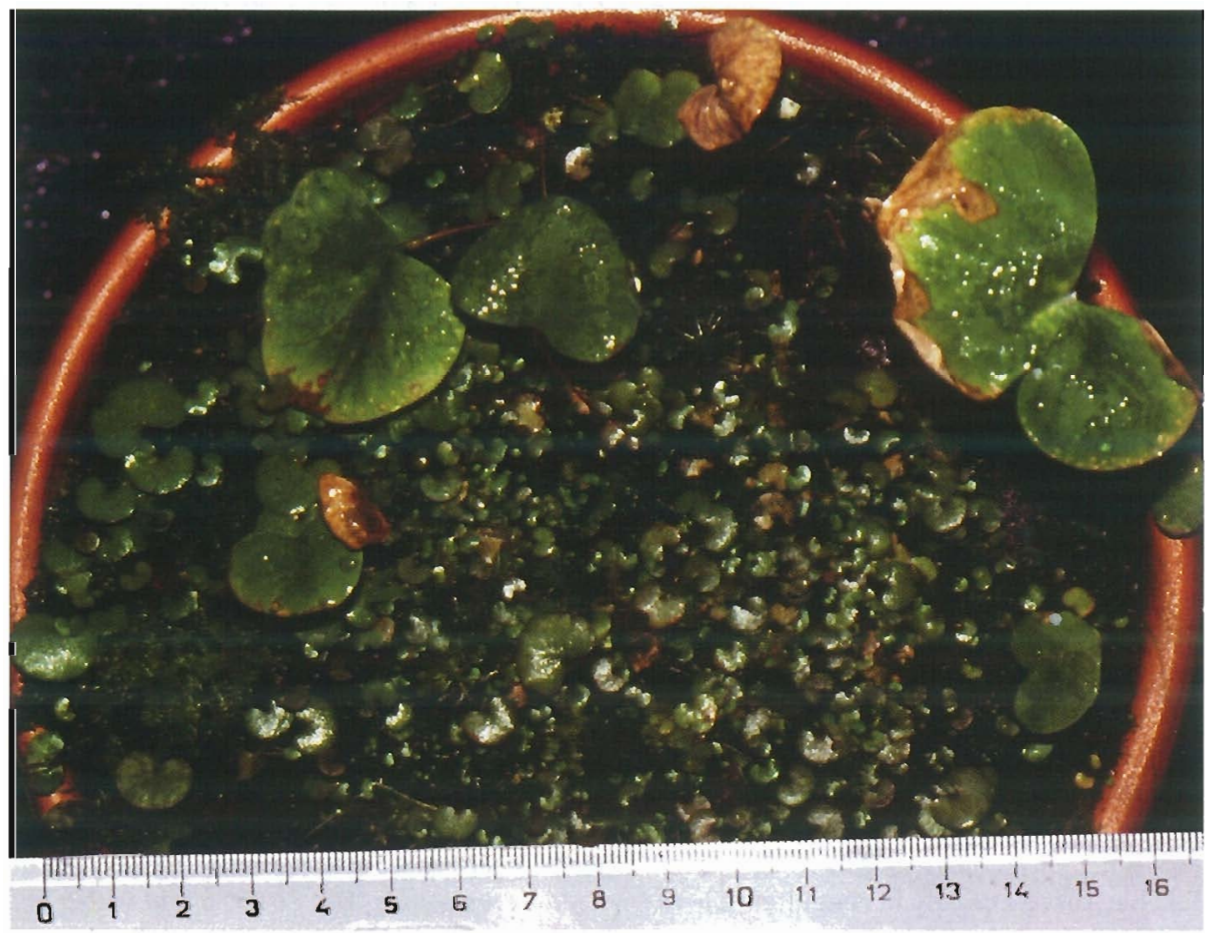

Figure 2: Minuscule ground-leaves of Utricularia reniformis Enfant Terrible, as they are seen below the aerial leaves. Photograph by Miloslav Studnicka. 
means should be appraised carefully regarding vigor. If they produce small aerial-leaves and the minute ground-leaves, they would be considered specimens of Utricularia reniformis 'Enfant Terrible'.

Additional aspects of this cultivar are discussed in the article on page 47.

—Barry Rice • P.O. Box 72741 • Davis, California -USA • barry@sarracenia.com -Miloslav Studnicka - Botanic Gardens Liberec - Purkynova I •460 01 Liberec • Czech Republic

\section{BoARd MEMBER EleCtions}

The end of this year will mark the end of terms of office for three ICPS board members: Cindy Slezak (Vice President), John Brittnacher (Secretary), and Jan Schlauer (representing our editorial board). These three officers oversaw the ICPS during its major restructuring in which it gained 501(c)3 nonprofit status, became able to process VISA payments, completely restructured our seed bank, and adopted an electronic editorial process to simplify and speed the publication to our journal, Carnivorous Plant Newsletter. The other board members, as well as all the additional volunteers responsible for operating the ICPS, extend their thanks to these officers for the work they have done during their terms of office.

All three anticipate running for another term, but hard working members of the ICPS are encouraged to run for a board position. Please send a 250 word election statement to Barry Rice (contact information is on the inside cover of Carnivorous Plant Newsletter). Your election statements must be received by 1 August, 2004. In your statement, you may wish to note your experience, why you want to run for office, and what you wish to accomplish. Your statements will be printed in the September issue.

The ICPS is a growing, active organization. In order to participate as a board member, email access is essential. Furthermore, board members are expected to work hard! So while we welcome and encourage your interest as a board member, remember that it is more than a vanity post!

\section{LOOKING BACK: CPN 25 YEARS AGO}

Don Schnell noted that the great Yellow River site in Florida, famous for its pitcher plants, had an ominous For Sale sign: "Perhaps one of our Florida subscribers would like to check into this for us and let us know about acreage involved, exact portions of the location involved, cost, etc. There was no sign on the west side of the road, this being the side with the large open, disturbed wet area supporting tremendous growth of Sarracenia rubra and its hybrids with $S$. leucophylla."

In 2001 Bob Hanrahan took me (Barry Rice) back to the site, and we found that it had been completely destroyed. I managed to find one small plant each of Drosera intermedia and Drosera capillaris. The rest was gone.

In the News and Views section, page 37, John Watkins noted that he was interested in starting a carnivorous plant society in Great Britain. Was he successful? Ask any of the now 500 members of The Carnivorous Plant Society, or visit their great web site (http://www.thecarnivorousplantsociety.org) to find out for yourself! 

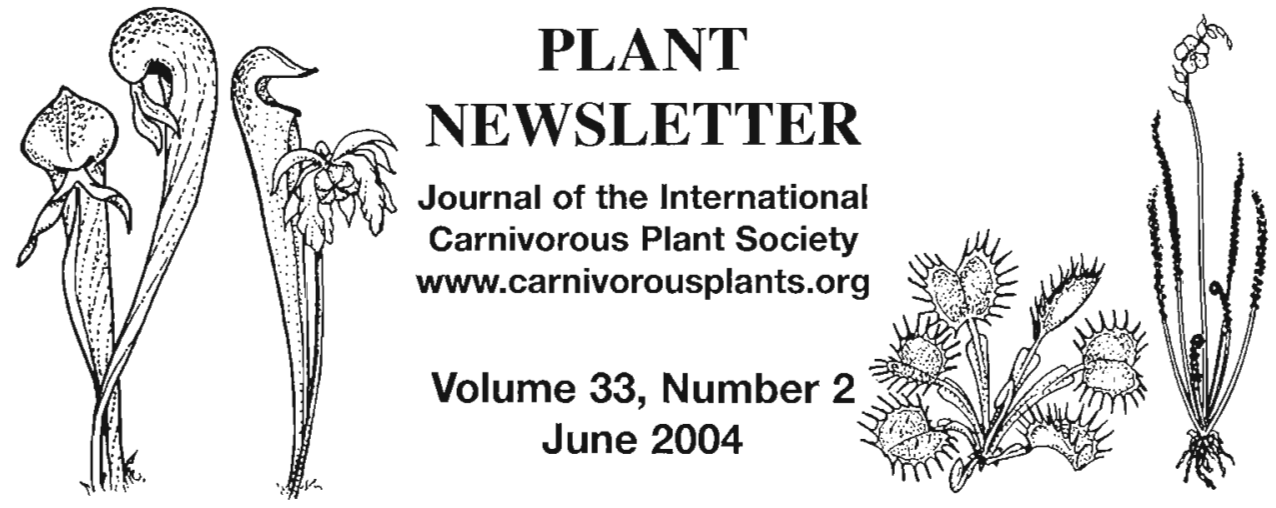

Front Cover: Drosera spatulata 'Ruby Slippers'. Photograph by William Joseph Clemens. Article on page 52.

Back Cover: A leaf blade of Utricularia reniformis 'Big Sister', measuring $175 \mathrm{~mm}$ across, documented in Serra dos Órgãos, Brazil. Photograph by Miloslav Studnicka. See article on page 52.

Camivorous Plant Newsletter is dedicated to spreading knowledge and news related to carnivorous plants. Reader contributions are essential for this mission to be successful. Do not hesitate to contact the editors with information about your plants, conservation projects, field trips, or noteworthy events. Contributors should review the "Instructions to Authors" printed in the March issue of each year. Advertisers should contact the editors. Views expressed in this publication are those of the authors, not the editorial staff.

All correspondence regarding dues, address changes and missing issues should be sent to the Membership Coordinator at the ICPS. Do not send such correspondence to the editors. Checks for subscriptions and back issues should be made to the ICPS in US funds. Dues for 2004 are $\$ 25$.

\author{
ICPS, Inc. \\ PMB 330 \\ 3310 East Yorba Linda Blvd. \\ Fullerton, CA 92831-1709, USA \\ icps@carnivorousplants.org
}

President

Vice President

Carl Mazur, email: carl@carnivorousplants.org

Treasurer

Secretary, Seed Bank

Board Member

Board Member

Cindy Slezak, email: cindy @carnivorousplants.org

Richard Myers, email: richard@carnivorousplants.org

John Brittnacher, email: john@carnivorousplants.org, seedbank listed in this issue.

Chris Teichreb, email: chris@carnivorousplants.org

Steve LaWarre, email: stevel@carnivorousplants.org

Editors:

Barry A. Rice, P.O. Box 72741, Davis, CA 95617, USA, email: barry@ carnivorousplants.org

Jan Schlauer, Zwischenstr. 11, D-60594 Frankfurt, Germany, email: jan@carnivorousplants.org

Page Layout: Steve Baker, email: steve@carnivorousplants.org

Date of effective publication of the March 2004 issue of Camivorous Plant Newsletter: 9 March 2004.

The ICPS is the International Cultivar Registration Authority (ICRA) for cultivated carnivorous plants according to The International Code For The Nomenclature of Cultivated Plants. Send relevant correspondence to the ICPS, Inc.

PUBLISHER: ICPS, Inc., Fullerton, California. Published quarterly with one volume annually. Desktop Publishing: Steve Baker, 5612 Creek Point Drive, Hickory, NC 28601. Printer: Kandid Litho. Logo and masthead art: Paul Milauskas. Dues: $\$ 25.00$ annually. (C) 2004 Carnivorous Plant Newsletter: All rights reserved. ISSN \#0190-9215. 


\section{CARNIVOROUS PLANT NEWSLETTER}

Journal of the International Carnivorous Plant Society

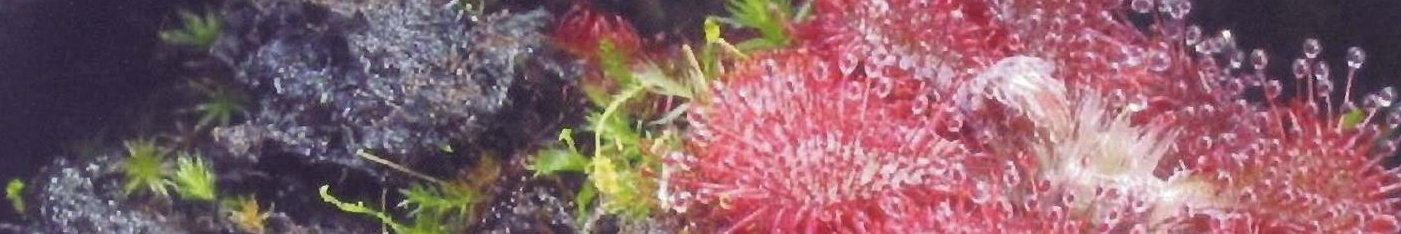

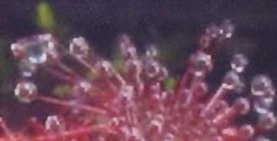

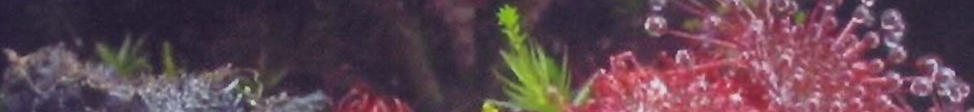

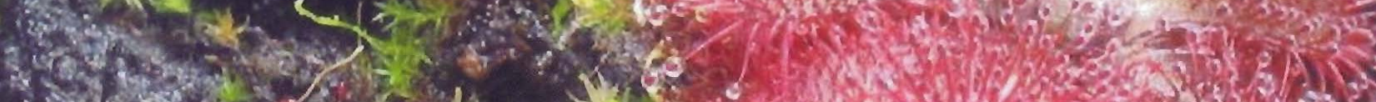
- 10.1 .

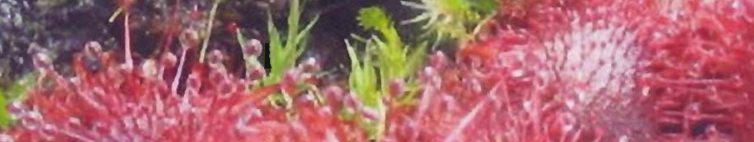

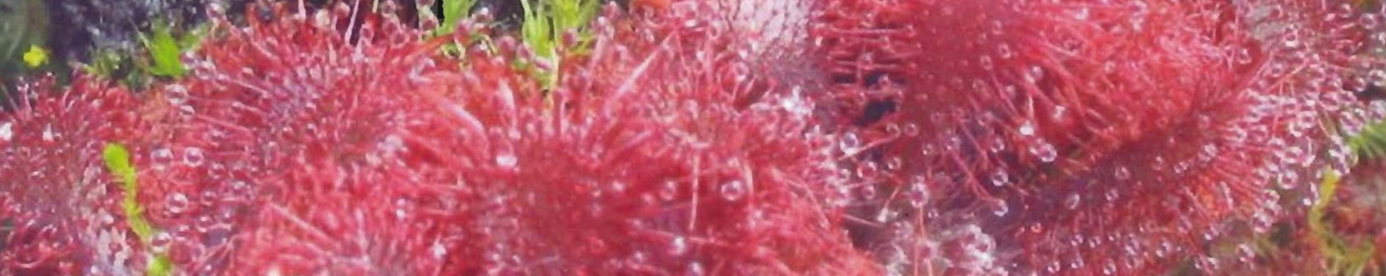

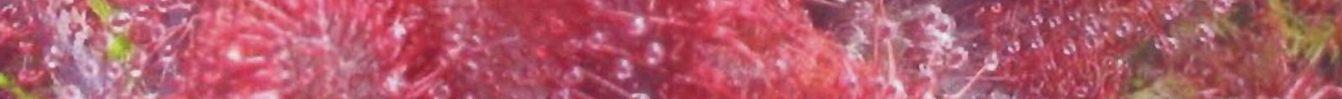

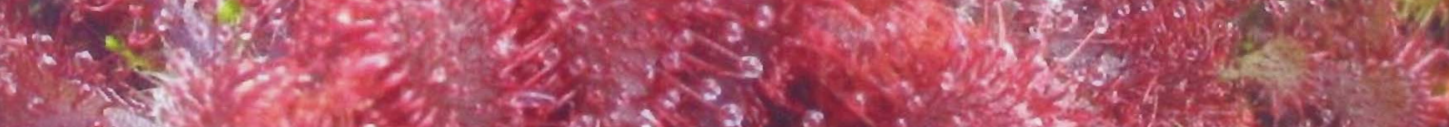

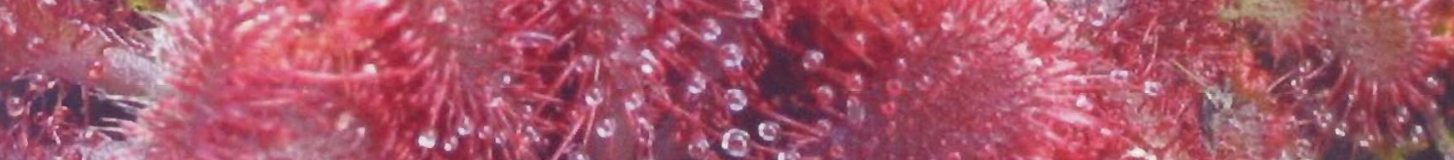

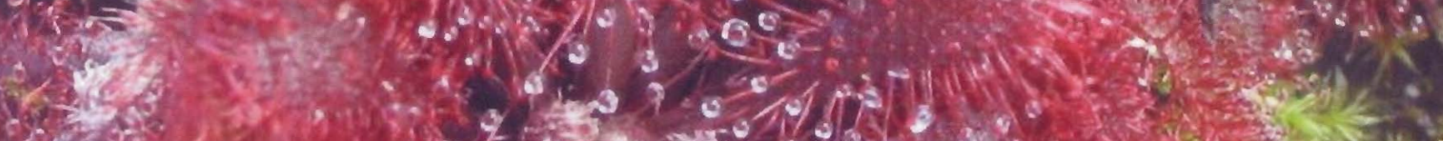

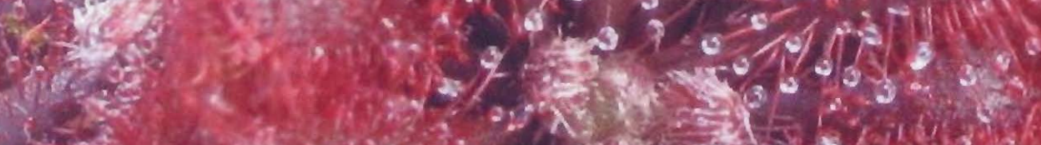

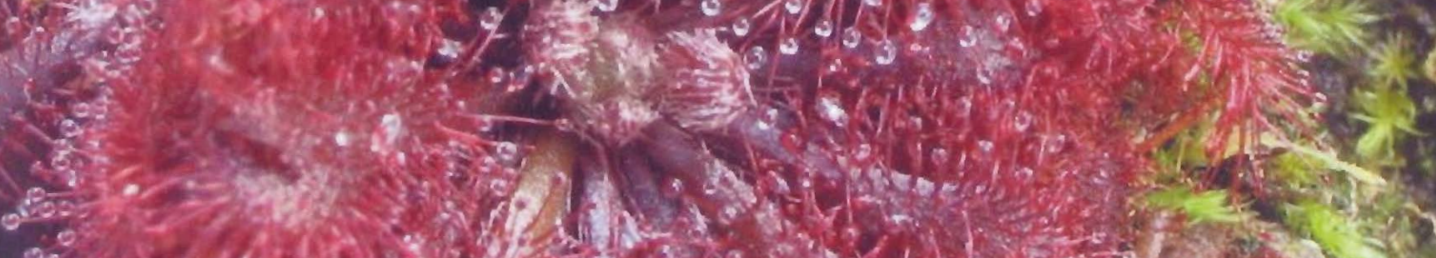

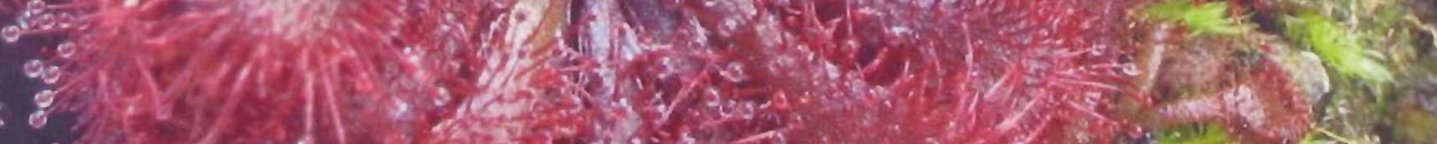
(15:

$$
\therefore-1,2, \frac{3}{3}
$$

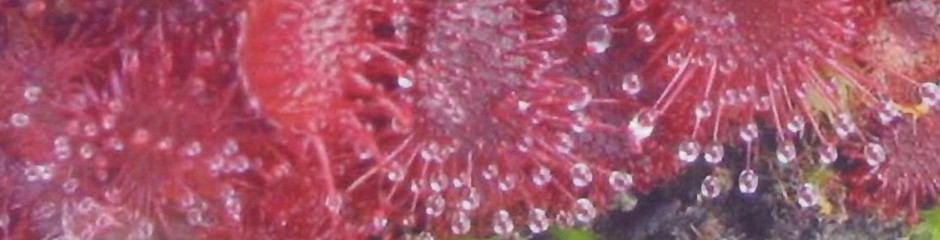
$30 \times 3$ 


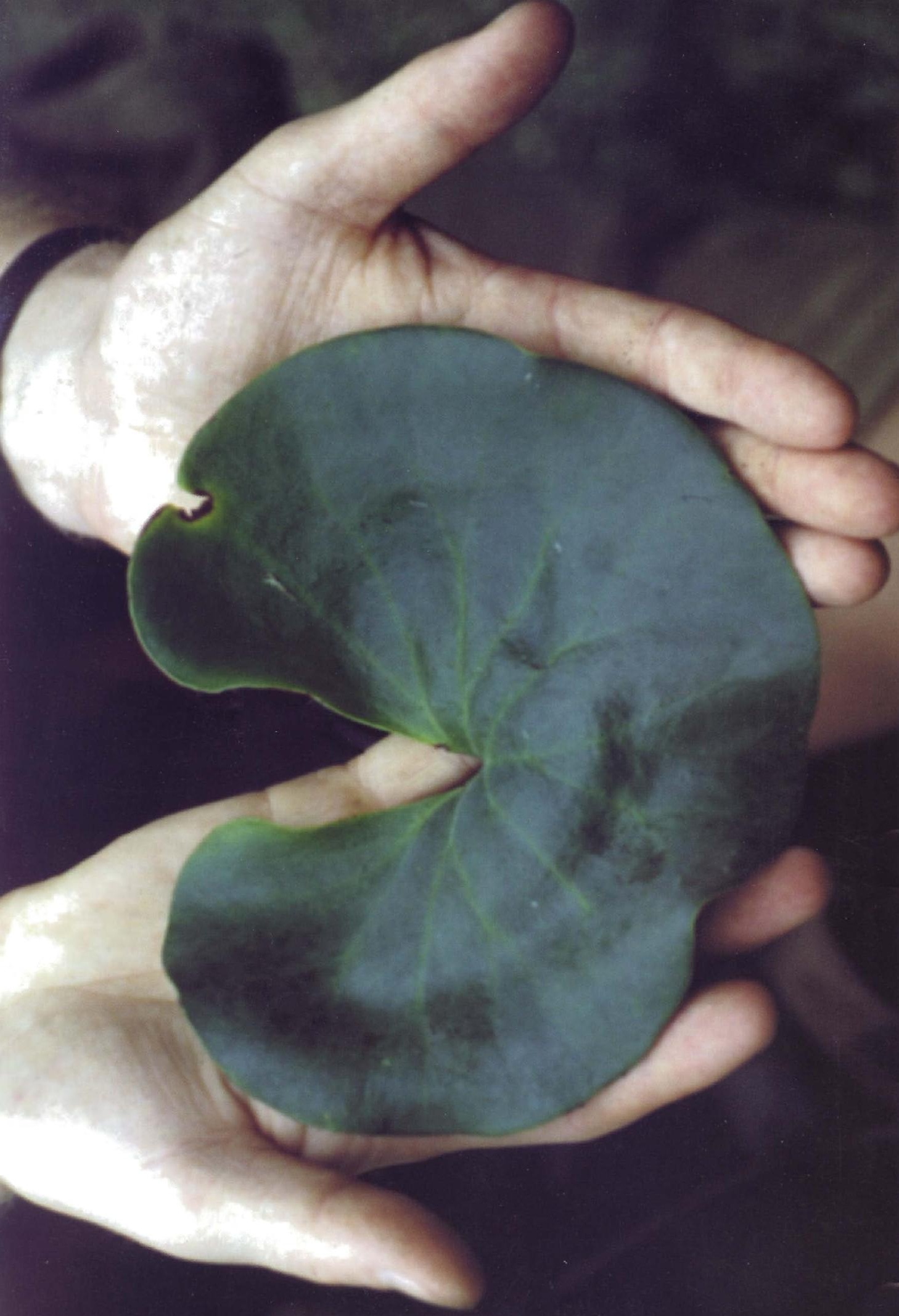

